\section{Temperature and Daily Light Integral Influence Plant Quality and Flower Development of Campanula carpatica 'Blue Clips', 'Deep Blue Clips', and Campanula 'Birch Hybrid'}

\author{
Genhua Niu, Royal D. Heins ${ }^{1}$, Arthur Cameron, and Will Carlson \\ Department of Horticulture, Michigan State University, East Lansing, \\ MI 48824-1325
}

\section{Additional index words. flower size, flower bud number}

\begin{abstract}
The effects of temperature on flower size and number of flower buds of Campanula carpatica Jacq. 'Blue Clips', 'Deep Blue Clips', and Campanula 'Birch Hybrid' were investigated in four temperature and light-transfer experiments. In year 1, 'Blue Clips' and 'Birch Hybrid' plants were grown initially at $20{ }^{\circ} \mathrm{C}$ and then transferred at visible flower bud (VB) to 14, 17, 20, 23, or $26^{\circ} \mathrm{C}$ until flower (Expt. 1). In Expt. 2, 'Blue Clips' and 'Birch Hybrid' plants were transferred from 14 to $26^{\circ} \mathrm{C}$ or from 26 to $14{ }^{\circ} \mathrm{C}$ at various intervals after flower induction. Flower size of both species was negatively correlated with average daily temperature (ADT) after VB; flowers on plants grown at $14{ }^{\circ} \mathrm{C}$ were $35 \%$ larger than those on plants grown at $26^{\circ} \mathrm{C}$. In contrast, temperature before VB had only a small effect on final flower size in both species, although flower diameter of 'Birch Hybrid' plants grown at constant $26^{\circ} \mathrm{C}$ was $20 \%$ smaller than that of the plants grown initially at $20^{\circ} \mathrm{C}$ and then transferred to $\mathrm{VB}$ to $26^{\circ} \mathrm{C}$. For both species, the longer the exposure to high temperature after $\mathrm{VB}$, the smaller the flowers. Number of flower buds at flower in 'Birch Hybrid' decreased as ADT after VB increased. In year 2, 'Deep Blue Clips' plants were grown at constant $20{ }^{\circ} \mathrm{C}$ under high or low daily light integral (DLI, 17 or $5.7 \mathrm{~mol} \cdot \mathrm{m}^{-2} \cdot \mathrm{d}^{-1}$ ) until VB, and then transferred to $14,17,20,23$, or $26{ }^{\circ} \mathrm{C}$ under high or low DLI (Expt. 3). In Expt. 4, 'Deep Blue Clips' plants were grown at $14,17,20,23$, or $26{ }^{\circ} \mathrm{C}$ until $\mathrm{VB}$, and then transferred to constant $20{ }^{\circ} \mathrm{C}$ under high or low DLI until flower. Flower size (petal length) was negatively correlated with ADT both before and after VB, while flower bud number was negatively correlated with the ADT only after VB, regardless of DLI. In both experiments, petal length decreased by 0.3 to $0.5 \mathrm{~mm}$ per $1{ }^{\circ} \mathrm{C}$ increase in ADT before or after $\mathrm{VB}$. Flowers were larger and more numerous under high than under low DLIs after VB, regardless of the DLI before VB.
\end{abstract}

The Campanulaceae include $>700$ species that are annual, biennial, or perennial. Campanula carpatica 'Blue Clips', 'Deep Blue Clips', and Campanula 'Birch Hybrid' are popular garden perennial species that have numerous, blue, bell-shaped flowers and can be grown as flowering potted plants. 'Blue Clips' (Whitman et al., 1997) and 'Deep Blue Clips' (unpublished data) plants have no vernalization requirement and have an obligate long-day requirement for flowering, while 'Birch Hybrid' (Finical et al., 1998) plants have an obligate vernalization requirement but are day-neutral for flowering.

Flower size and number, important quality attributes for many floral crops, generally decrease as temperature increases. This phenomenon has been noted in C. carpatica 'Blue Clips' (Niu et al., 2001; Whitman et al., 1997),

Received for publication 28 Jan. 2000. Accepted for publication 13 Oct. 2000. The cost of publishing this paper was defrayed in part by the payment of page charges. Under postal regulations, this paper therefore must be hereby marked advertisement solely to indicate this fact.

${ }^{1}$ To whom reprints requests should be addresed. E-mail address: heins@msu.edu
C. 'Birch Hybrid' (Frane, 1999), and pansy 'Universal Violet' (Viola ×wittrockiana Gams.) (Pearson et al., 1995). Increasing daily light integral (DLI) can compensate for the negative effect of high temperatures in many cases. More and larger flowers of $C$. carpatica 'Blue Clips' were obtained at 20 to $22{ }^{\circ} \mathrm{C}$ under DLI of $10 \mathrm{~mol} \cdot \mathrm{m}^{-2} \cdot \mathrm{d}^{-1}$ compared to those at 16 to $18^{\circ} \mathrm{C}$ under DLI of $4 \mathrm{~mol} \cdot \mathrm{m}^{-2} \cdot \mathrm{d}^{-1}$ (Niu et al., 2001). Supplementary lighting for $22 \mathrm{~d}$ during greenhouse production increased the size and number of C. carpatica 'Karl Foerster' flowers during the marketing and postharvest periods (Serek, 1991).

Stage of growth may affect response to environmental conditions. Pearson et al. (1995) reported that increasing temperature before visible bud (VB) had little effect on flower size of pansy 'Universal Violet', but affected flower size in all subsequent bud developmental stages. If other species respond to temperature as does pansy, such information might be used to maintain or improve plant quality by adjusting temperature during crop development. Whether the effect of DLI on flower size and number varies with developmental stages is not known.
There are several phases during the flowering process: flower induction, which is the initial biochemical changes that lead to flowering; flower initiation, during which the flower bud or inflorescence can be first identified under a microscope; bud or inflorescence development or expansion; and, finally, anthesis. Since VB can easily be identified macroscopically, the objectives of this study were to investigate when flowers of 'Blue Clips', 'Deep Blue Clips', and 'Birch Hybrid' were responsive to temperature during flower development and determine how DLI before or after VB affected flower size and number of 'Deep Blue Clips'.

\section{Materials and Methods}

Year 1

General plant culture. 'Blue Clips' seedlings with three to five true leaves were received from a commercial producer in 128cell trays $(10-\mathrm{mL}$ cell volume) on 15 Oct. 1998. Upon receipt, seedlings were placed in a greenhouse maintained at $20 \pm 2{ }^{\circ} \mathrm{C}$ under natural daylength. They were transplanted to $10-\mathrm{cm}(470-\mathrm{mL})$ containers when they averaged seven leaves. A commercial medium (Strong-Lite High Porosity Mix, Pine Bluff, Ark.), composed of pine bark, fibrous Canadian sphagnum peat, horticultural vermiculite, and screened coarse perlite, together with a wetting agent, was used. 'Birch Hybrid' rooted cuttings in 70-cell trays were received from a commercial producer on 26 July 1998. Upon receipt, plants were stored for 15 weeks in a cooler at $5{ }^{\circ} \mathrm{C}$ under a photosynthetic photon flux $(P P F)$ of $10 \mu \mathrm{mol} \cdot \mathrm{m}^{-2} \cdot \mathrm{s}^{-1}$. Before transfer to the greenhouses for temperature treatments, the cuttings were planted in $13-\mathrm{cm}$ square (1.1-L volume) plastic containers containing the same commercial medium used for 'Blue Clips'. Plants of both species were irrigated as necessary with well water [electrical conductivity (EC) of $0.7 \mathrm{mS} \cdot \mathrm{cm}^{-1}$ and 105 , 35 , and $23 \mathrm{mg} \cdot \mathrm{L}^{-1}$ of $\mathrm{Ca}, \mathrm{Mg}$, and $\mathrm{S}$, respectively], which was acidified with $\mathrm{H}_{2} \mathrm{SO}_{4}$ to a titratable alkalinity of $130 \mathrm{mg} \cdot \mathrm{L}^{-1}$ of $\mathrm{CaCO}_{3}$ and contained water-soluble fertilizer providing $\left(\mathrm{mg} \cdot \mathrm{L}^{-1}\right): 125 \mathrm{~N}, 12 \mathrm{P}, 125 \mathrm{~K}, 13 \mathrm{Ca}(30 \%$ ammoniacal $\mathrm{N})$ and $\left(\mathrm{mg} \cdot \mathrm{L}^{-1}\right) 1.0 \mathrm{Fe}, 0.5 \mathrm{Mn}$ $0.5 \mathrm{Zn}, 0.5 \mathrm{Cu}, 0.1 \mathrm{~B}, 0.1 \mathrm{Mo}$ (MSU Special, Greencare Fertilizers, Chicago). Supplemental lighting at a $P P F$ of $150 \mu \mathrm{mol} \cdot \mathrm{m}^{-2} \cdot \mathrm{s}^{-1}$ was provided from 6:00 $\mathrm{AM}$ to 10:00 $\mathrm{PM}$ and the measured DLI was $\approx 12 \mathrm{~mol} \cdot \mathrm{m}^{-2} \cdot \mathrm{d}^{-1}$.

Experimental design. In Expt. 1, plants of both species were initially grown in a glass greenhouse set at constant $20^{\circ} \mathrm{C}$. Plants were assigned to treatments and, when the first terminal flower buds were visible, transferred individually to greenhouse sections set at 14 , $17,20,23$, or $26^{\circ} \mathrm{C}$. In Expt. 2, transfers were made at different intervals between greenhouse sections set at 14 and $26^{\circ} \mathrm{C}$. In addition, two groups of both species were grown at constant 14 or $26{ }^{\circ} \mathrm{C}$ throughout the experimental period. The starting dates in both experiments were 9 Nov. 1998 for 'Birch Hybrid' and 13 Nov. 1998 for 'Blue Clips'. 
The number of plants per treatment was ten for 'Blue Clips' and six for 'Birch Hybrid'. A total of nine of the 'Birch Hybrid' plants did not flower; data for those plants were not included in analyses.

Dates of the first VB and flower were recorded, as well as the diameter of the first open flower. For 'Birch Hybrid' plants, the number of flower buds per shoot at flower was recorded for two shoots.

\section{Year 2}

General plant culture. Seedlings of $C$. carpatica 'Deep Blue Clips' with three true leaves were received from a commercial producer in 128-cell trays on 4 Sept. 1999. Upon receipt, seedlings were placed in a greenhouse maintained at $20 \pm 2{ }^{\circ} \mathrm{C}$ under natural photoperiods. When seedlings had produced an average of seven leaves, they were transplanted to 10$\mathrm{cm}$ (470-mL) containers, grown in a commercial medium (Peat-Perlite Mix, Michigan Grower Products, Galesburg, Mich.), and irrigated with the same type of nutrient solution used in year 1 .

In both years, greenhouse temperatures were controlled by a greenhouse climate-control computer (model CD750, Priva; De Lier, The Netherlands). Plant temperatures were measured throughout the experimental period by inserting thermocouples (chromel-constantan, $0.127 \mathrm{~mm}$ in diameter) into shoot tips. The thermocouples were reinserted to a new position every 1 to 2 weeks as plants grew. Vapor pressure deficit (VPD) was maintained around $0.7 \mathrm{KPa}$ in all sections by injecting water vapor as needed. Actual temperatures (air and plant) and $P P F$ were measured at 10 -s intervals, and the hourly average was recorded by a CR-10 datalogger (Campbell Scientific, Logan, Utah). The actual plant average daily temperature (ADT) from forcing to VB (majority of the plants), from VB to flower, and from forcing to flower over the entire experimental period were calculated and used in all data analyses.

Experimental design. Five greenhouse sections $(4.7 \times 4.1 \mathrm{~m})$ were set at $14,17,20,23$, or $26^{\circ} \mathrm{C}$, and each section had two DLI levels. One of the three benches (high DLI bench; average $\left.17 \mathrm{~mol} \cdot \mathrm{m}^{-2} \cdot \mathrm{d}^{-1}\right)$ in each greenhouse section was lighted by high-pressure sodium (HPS) lamps at an average $215 \mu \mathrm{mol} \cdot \mathrm{m}^{-2} \cdot \mathrm{s}^{-1}$ for $16 \mathrm{~h} \cdot \mathrm{d}^{-1}$. The low DLI bench $\left(5.7 \mathrm{~mol} \cdot \mathrm{m}^{-2} \cdot \mathrm{d}^{-1}\right)$ was separated from the high DLI bench by another bench and had a $P P F$ of $\approx 10 \mu \mathrm{mol} \cdot \mathrm{m}^{-2} \cdot \mathrm{s}^{-1}$ provided by lights over the high DLI bench, a $P P F$ sufficient to provide a long-day photoperiod. In Expt. 3, plants with $12-15$ nodes were grown in a $20^{\circ} \mathrm{C}$ greenhouse section under high or low DLI until VB and were moved individually to greenhouse sections set at $14,17,20,23$, or $26^{\circ} \mathrm{C}$ under high or low DLI in a factorial fashion and remained there until flower. In Expt. 4, plants with 12 to 15 nodes were placed under long days at $14,17,20,23$, or $26^{\circ} \mathrm{C}$ until they were individually moved to $20^{\circ} \mathrm{C}$ under high or low DLI at VB, where they remained until flower. A group of 12 control plants was grown on each bench at constant temperature and DLI throughout the experimental period.
Dates of VB and first flower were recorded. Petal length and number of flower buds were also recorded. SAS's PROC REG (SAS Institute, Cary, N.C.) was used to test the significance of correlation, and PROC GLM was used to test the significance of differences between regression lines. The linear regression lines are presented in the graphs only when the correlation was statistically significant.

In order to determine when flower buds were initiated, plants with $\approx 15$ nodes were placed under long days at 14,20 , or $26^{\circ} \mathrm{C}$ on 20 Dec. 1999. Six plants were dissected and viewed under a microscope every other day to determine whether flower buds had been initiated. The date on which all six plants reached flower bud initiation and the date of first VB were recorded.

\section{Results and Discussion}

\section{Year 1}

'Blue Clips'. Flower diameter in both experiments was negatively correlated with ADT after VB (Fig. 1A). Flower diameter in Expt. 1 was largest when plants were grown at constant $14{ }^{\circ} \mathrm{C}$ or grown initially at $20^{\circ} \mathrm{C}$ until VB and then transferred to 14 or $17{ }^{\circ} \mathrm{C}$ until flower, and smallest when plants were grown at constant $26^{\circ} \mathrm{C}$ or grown initially at $20^{\circ} \mathrm{C}$ and then transferred to $26{ }^{\circ} \mathrm{C}$ at VB.

In Expt. 2, flower diameter of plants that were transferred from 26 to $14{ }^{\circ} \mathrm{C}$ before VB (Fig. 1A) did not differ significantly from that of plants held in constant $14{ }^{\circ} \mathrm{C}$. Similarly, flower diameter of plants that were transferred from 14 to $26{ }^{\circ} \mathrm{C}$ before VB (W1-14-26 and W3-14-26) did not differ from that in constant $26{ }^{\circ} \mathrm{C}$.

Flower diameter of 'Blue Clips' plants that were transferred from 26 to $14^{\circ} \mathrm{C} \approx 2$ weeks after VB (W5-26-14) was smaller than that of plants held at constant $14{ }^{\circ} \mathrm{C}$, but larger than that of those at constant $26{ }^{\circ} \mathrm{C}$ (Fig. 1A). Similarly, flower diameter of plants that were transferred $\approx 3 \mathrm{~d}$ after $\mathrm{VB}$ from 14 to $6{ }^{\circ} \mathrm{C}$ (W514-26) was larger than the flower diameter of plants grown at $26^{\circ} \mathrm{C}$, but smaller than that at $14{ }^{\circ} \mathrm{C}$.

The results indicate that when 'Blue Clips' plants were grown at cool temperatures initially and transferred to warm temperatures at or before VB, the final flower diameter was comparable to that of plants grown at warm temperatures throughout. Conversely, when plants were grown at warm temperatures initially and transferred to cool temperatures at or before VB, the flower diameter was similar to that of plants grown at a constant cool temperature. The longer the plants were exposed to warm temperatures after VB, the smaller the flower. After VB, plants grown part of the time at a cool temperature and part at a warm one had an intermediate flower size that was negatively correlated with ADT (Fig. 1A).

'Birch Hybrid'. Flower diameter increased as temperature after VB decreased. In Expt. 1 , flower diameter of plants grown at constant $14{ }^{\circ} \mathrm{C}$ did not differ from that of the plants grown initially at $20^{\circ} \mathrm{C}$ and then trans-

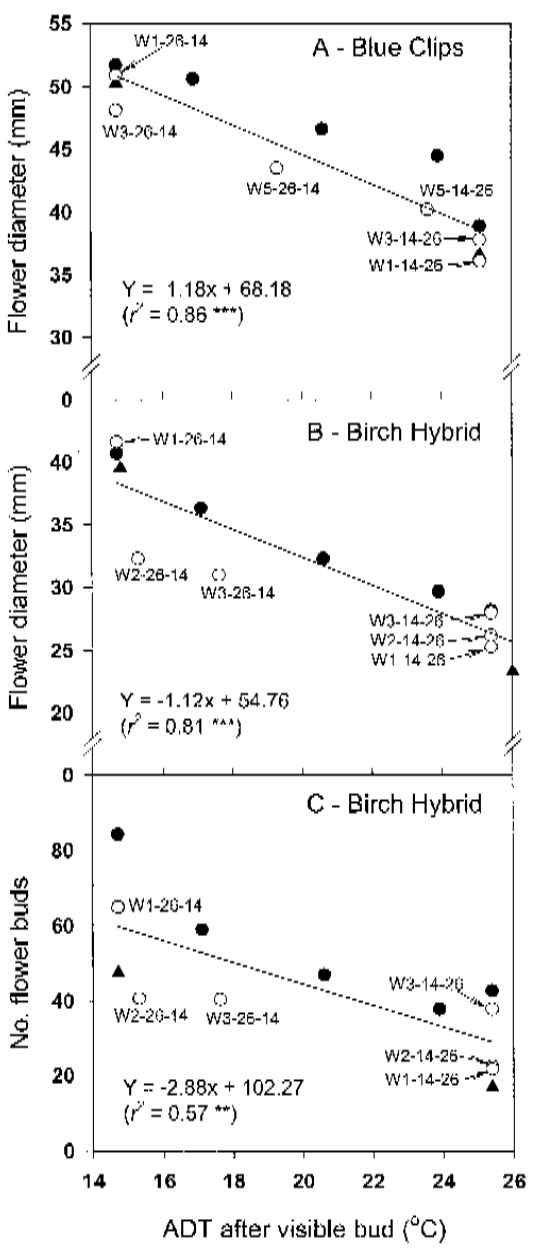

Fig. 1. Relationship between average daily temperature (ADT) after visible bud and (A) flower diameter of Campanula carpatica 'Blue Clips', (B) flower diameter of Campanula 'Birch Hybrid', and (C) the number of flower buds of 'Birch Hybrid'. Symbols represent means for plants grown at $20{ }^{\circ} \mathrm{C}$ and then transferred to various temperatures at visible bud (O) (Expt. 1), plants transferred from 14 to $26^{\circ} \mathrm{C}$ or from 26 to $14{ }^{\circ} \mathrm{C}$ at different time intervals ( $\left.\mathrm{O}\right)$ (Expt. 2), or constant 14 or $26^{\circ} \mathrm{C}(\boldsymbol{\Delta})$, respectively. The solid line represents the linear regression line from all the data points.

ferred to $14{ }^{\circ} \mathrm{C}$ at VB (Fig. 1B). However, flower diameter at constant $26^{\circ} \mathrm{C}$ was $20 \%$ smaller than that of the plants grown initially at $20^{\circ} \mathrm{C}$ and then transferred to $26^{\circ} \mathrm{C}$ at VB. When plants were grown initially at $20{ }^{\circ} \mathrm{C}$ and then transferred at VB to $14,17,20$, or 23 ${ }^{\circ} \mathrm{C}$, the lower the temperature after VB, the larger the flowers. Flower diameter was $\approx 25 \%$ or $60 \%$ larger at constant $14{ }^{\circ} \mathrm{C}$ than at constant 20 or $26^{\circ} \mathrm{C}$.

In Expt. 2, flower diameter of plants grown at $26^{\circ} \mathrm{C}$ for 1 week and then transferred to $14{ }^{\circ} \mathrm{C}$ (W1-26-14) was the same as that of plants grown at constant $14{ }^{\circ} \mathrm{C}$ (Fig. 1B). Flower diameter following transfer from 26 to $14{ }^{\circ} \mathrm{C}$ after VB (W2-26-14 and W3-26-14) was intermediate between those at constant $14{ }^{\circ} \mathrm{C}$ and constant $26^{\circ} \mathrm{C}$, whereas diameter following transfer from 14 to $26^{\circ} \mathrm{C}$ before VB (W1-14-26) was the same as at constant 
$26^{\circ} \mathrm{C}$ (Fig. 1B). In W2-14-26 and W3-14-26, some plants were transferred from 14 to $26^{\circ} \mathrm{C}$ after $\mathrm{VB}$, so the flower diameter was larger than that at constant $26^{\circ} \mathrm{C}$.

The number of flower buds per shoot in 'Birch Hybrid' also decreased linearly as ADT after VB increased but the correlation was low (Fig. 1C). In 'Blue Clips', the number of flower buds at first flower decreased as forcing temperature increased from 14 to $26^{\circ} \mathrm{C}$ (Niu et al., 2001; Whitman et al., 1997) but was not recorded in this study.

Flowers of 'Blue Clips' in W3-26-14, W526-14, W1-14-26, and constant 26 (Fig. 1A) and of 'Birch Hybrid' in W2-26-14, W3-2614, W1-14-26, and constant 26 (Fig. 1B) were smaller than the average (based on the linear regression line), since some or all of the plants in the treatments were exposed to $26^{\circ} \mathrm{C}$ during early flower bud development (Table 1 ). Generally, flowers of both species were larger in Expt. 1 than in Expt. 2 at the same ADT after VB, although differences were not significant. The tendency toward smaller flowers in Expt. 2 suggests that exposure to $26^{\circ} \mathrm{C}$ from flower initiation to $\mathrm{VB}$ had at least some effect on final flower size.

Time from VB to flower decreased as ADT from VB to flower increased for both species (Fig. 2), which agrees with previous reports (Frane, 1999; Whitman et al., 1997). Time from $\mathrm{VB}$ to flower decreased $\approx 2$ weeks as ADT increased from 15 to $20^{\circ} \mathrm{C}$ (Fig. $2 \mathrm{~A}$ and B). Frane (1999) reported that flower developmental rate in 'Birch Hybrid' increased as temperature increased from 17 to $24{ }^{\circ} \mathrm{C}$ but decreased as temperature continued to increase from 24 to $29^{\circ} \mathrm{C}$. In this study, time from VB to flower decreased as ADT increased from 14 to $24^{\circ} \mathrm{C}$, but did not change as ADT increased from 24 to $26^{\circ} \mathrm{C}$ (Fig. $2 \mathrm{~A}$ and B). Therefore, $26{ }^{\circ} \mathrm{C}$ is probably out of the linear range for flower development in both species. Flower developmental rate in 'Blue Clips' increased linearly with ADT from 14 to $25^{\circ} \mathrm{C}$, regardless of the combinations of day and night temperatures (Niu et al., 2001).

For both species, increasing the temperature hastened flower development but reduced flower size and number. Flower size was negatively correlated with the temperature after VB. Although the specific effect of all temperatures before $\mathrm{VB}$ on final flower size is not clear from this study, high temperature $\left(26^{\circ} \mathrm{C}\right)$ before VB did reduce flower size slightly.

\section{Year 2}

'Deep Blue Clips'. Flower size (petal length) and number of flower buds decreased as ADT increased (Fig. $3 \mathrm{~A}$ and D) for plants grown at a constant temperature, irrespective of the DLI from forcing to flower. The number of flower buds was higher under high $\left(17 \mathrm{~mol} \cdot \mathrm{m}^{-2} \cdot \mathrm{d}^{-1}\right)$ than under low DLI $\left(5.7 \mathrm{~mol} \cdot \mathrm{m}^{-2} \cdot \mathrm{d}^{-1} ;\right.$ Fig. 3D).

For plants grown initially at $20^{\circ} \mathrm{C}$ until VB and then transferred to various temperatures (Expt. 3), flower size and number of flower buds decreased linearly as ADT after VB increased under all DLIs (Fig. $3 \mathrm{~B}$ and E). Differences in slopes and intercepts of the

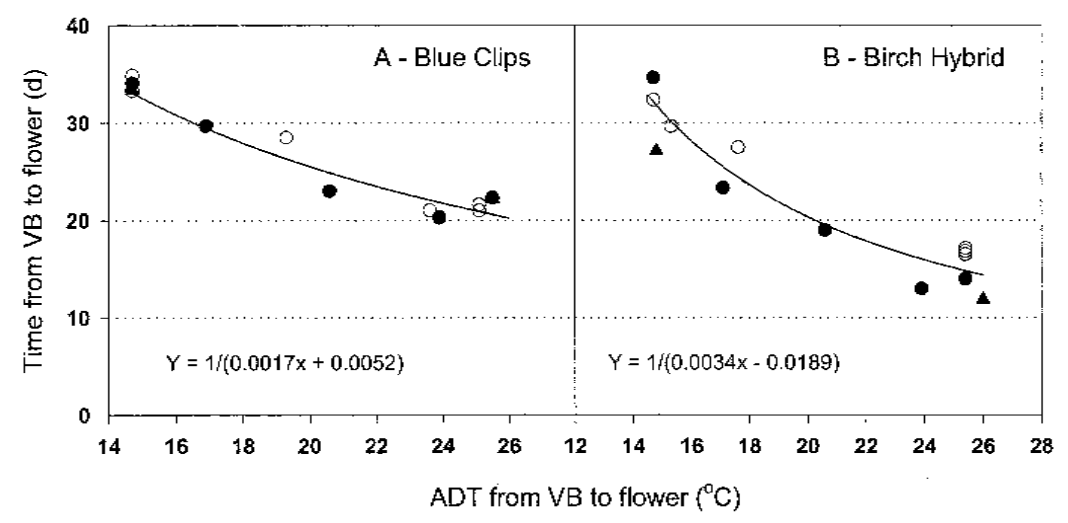

Fig. 2. Relationship between average daily temperature (ADT) and time from visible bud (VB) to flower of (A) Campanula carpatica 'Blue Clips' and (B) Campanula 'Birch Hybrid'. Symbols represent means for plants grown at $20^{\circ} \mathrm{C}$ and then transferred to various temperatures at visible bud (O) (Expt. 1), plants transferred from 14 to $26^{\circ} \mathrm{C}$ or from 26 to $14{ }^{\circ} \mathrm{C}$ at different time intervals (O) (Expt. 2), or constant 14 or $26^{\circ} \mathrm{C}(\boldsymbol{\Delta})$, respectively. The solid line represents the reciprocal of developmental rate pooled from all the data points. Developmental rate and ADT was correlated with $r^{2}$ of 0.92 ('Blue Clips') or 0.82 ('Birch Hybrid').

Table 1. Effect of time of transferring plants from 14 to $26^{\circ} \mathrm{C}$ or from 26 to $14{ }^{\circ} \mathrm{C}$ on days to visible bud (VB) of Campanula carpatica 'Blue Clips' and Campanula 'Birch Hybrid' (Expt. 2).

\begin{tabular}{|c|c|c|c|c|}
\hline \multirow{2}{*}{$\begin{array}{l}\text { Treatment } \\
\text { code }\end{array}$} & \multirow{2}{*}{$\begin{array}{c}\text { Time }(\mathrm{d}) \text { from } \\
\text { forcing to transfer }\end{array}$} & \multicolumn{2}{|c|}{$\operatorname{ADT}\left({ }^{\circ} \mathrm{C}\right)^{\mathrm{z}}$} & \multirow{2}{*}{$\begin{array}{l}\text { Time (d) from } \\
\text { forcing to VB }\end{array}$} \\
\hline & & Before VB & After VB & \\
\hline \multicolumn{5}{|c|}{ Blue Clips } \\
\hline Constant $14^{\circ} \mathrm{C}$ & --- & 14.7 & 14.7 & $32.6 \pm 0.9^{y}$ \\
\hline Constant $26^{\circ} \mathrm{C}$ & --- & 25.1 & 25.1 & $21.9 \pm 2.3$ \\
\hline \multicolumn{5}{|c|}{ Transfer from 26 to $14^{\circ} \mathrm{C}$} \\
\hline W1-26-14 & 7 & 17.3 & 14.7 & $28.1 \pm 5.0$ \\
\hline W3-26-14 & 21 & 22.7 & 14.7 & $27.4 \pm 8.9$ \\
\hline W5-26-14 & 35 & 25.1 & 19.3 & $22.4 \pm 2.5$ \\
\hline \multicolumn{5}{|c|}{ Transfer from 14 to $26^{\circ} \mathrm{C}$} \\
\hline W1-14-26 & 7 & 22.3 & 25.1 & $25.9 \pm 4.8$ \\
\hline W3-14-26 & 21 & 17.7 & 25.1 & $29.6 \pm 4.8$ \\
\hline W5-14-26 & 35 & 14.7 & 23.6 & $32.0 \pm 2.8$ \\
\hline \multicolumn{5}{|c|}{ Birch Hybrid } \\
\hline Constant $14^{\circ} \mathrm{C}$ & --- & 14.5 & 14.8 & $14.0 \pm 1.8$ \\
\hline Constant $26^{\circ} \mathrm{C}$ & --- & 26.1 & 26.0 & $12.5 \pm 3.0$ \\
\hline \multicolumn{5}{|c|}{ Transfer from 26 to $14^{\circ} \mathrm{C}$} \\
\hline W1-26-14 & 7 & 18.4 & 14.7 & $20.0 \pm 10.8$ \\
\hline W2-26-14 & 14 & 25.4 & 15.3 & $12.3 \pm 7.0$ \\
\hline W3-26-14 & 21 & 25.4 & 17.6 & $13.5 \pm 6.3$ \\
\hline \multicolumn{5}{|c|}{ Transfer from 14 to $26^{\circ} \mathrm{C}$} \\
\hline W1-14-26 & 7 & 21.1 & 25.4 & $17.5 \pm 7.8$ \\
\hline W2-14-26 & 14 & 16.5 & 25.4 & $16.8 \pm 8.7$ \\
\hline W3-14-26 & 21 & 14.7 & 25.4 & $21.0 \pm 9.5$ \\
\hline
\end{tabular}

${ }^{\mathrm{z}}$ Average daily temperature.

${ }^{\mathrm{y}}$ Means $\pm 95 \%$ confidence interval.

linear regression lines for flower size vs. ADT after VB were nonsignificant (Fig. 3B), provided that the DLI after VB was the same. Therefore, data were pooled under the same DLI after VB for linear regression lines (Fig. $3 \mathrm{~B}, \mathrm{C}$, and E). However, flower size and number of flower buds differed significantly when plants were grown under high (solid symbols) vs. low (open symbols) DLIs after VB (Fig. 3 B and E). Petal length decreased $\approx 0.5$ and $0.3 \mathrm{~mm}$ per $1{ }^{\circ} \mathrm{C}$ increase in ADT after VB under low and high DLIs, respectively (Fig. 3B). Plants averaged five fewer flower buds for every $1{ }^{\circ} \mathrm{C}$ rise in temperature after VB (Fig. 3E). Plants had $\approx 100$ more flower buds when grown under the high DLI after VB, regardless of the DLI before VB or temperature after VB (Fig. 3E).
Flower size of plants grown at various temperatures until VB and then transferred to $20^{\circ} \mathrm{C}$ (Expt. 4) was also negatively correlated with the temperature before VB (Fig. 3C). Except for the plants grown at low DLI before VB and high DLI after VB (solid triangle symbol, $r^{2}$ of 0.89 ), the number of flower buds was not influenced by the ADT before VB (Fig. 3F). Flowers were larger and flower buds were more numerous under high DLI after $\mathrm{VB}$, regardless of the DLI before VB.

Time from forcing to VB, from VB to flower, or from forcing to flower was unaffected by DLI before or after VB, and was closely correlated with ADT (Figs. 4-5). Time from VB to flower in Expt. 3 and from forcing to VB in Expt. 4 are not presented, since ADT was constant during those periods. Times from 


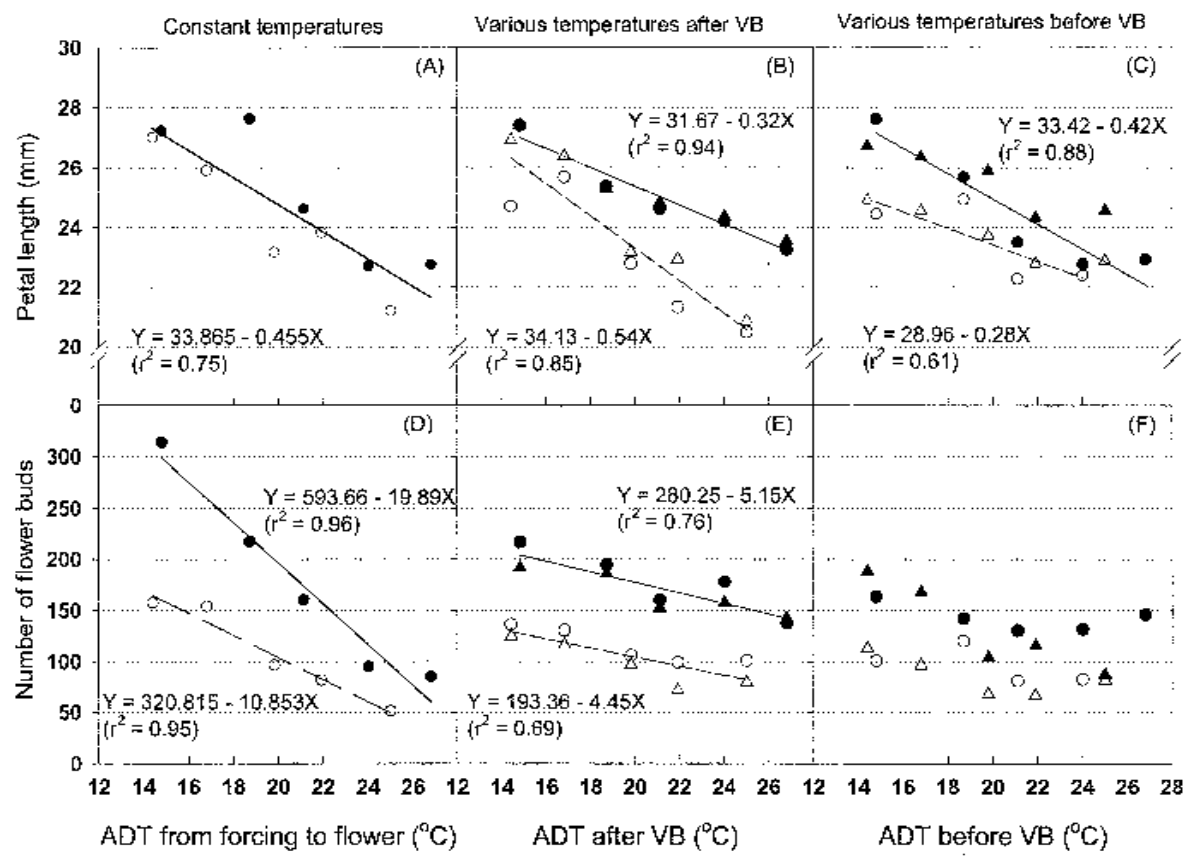

Fig. 3. Relationship between average daily temperature (ADT) and (A-C) flower petal length and (D-F) the number of flower buds of Campanula carpatica 'Deep Blue Clips'. Symbols indicate the DLI level before/after visible bud (VB): $\operatorname{High} / \operatorname{High}(\bullet), \operatorname{High} / \operatorname{Low}(\bigcirc)$, Low/High $(\boldsymbol{\Delta})$, and Low/Low $(\triangle)$. Solid and dashed lines represent linear regression lines for solid and open symbols, respectively.

forcing to VB, from VB to flower, or from forcing to flower decreased as ADT during those periods increased until $\approx 24{ }^{\circ} \mathrm{C}$, but increased or did not change as ADT continued to increase above $24{ }^{\circ} \mathrm{C}$. Flower developmental rate increases linearly as temperature increases between the base temperature, at which there is no growth, and the optimum temperature, at which developmental rate is maximum (Roberts and Summerfield, 1987). Therefore, the optimum temperature for rapid flower development for 'Deep Blue Clips' was $\approx 24^{\circ} \mathrm{C}$.

Time from flower induction (start of long days) to flower initiation and to VB and from flower initiation to VB were longest at $14{ }^{\circ} \mathrm{C}$ and shortest at $20^{\circ} \mathrm{C}$ in the temperature range studied (Table 2). Flower bud initiation was delayed $5 \mathrm{~d}$ when the temperature was raised from 20 to $26^{\circ} \mathrm{C}$.

In Expts. 3 and 4 , temperature before or after VB affected flower size, but only the temperature after VB affected the number of flower buds. Pearsonetal.(1995) concluded that flower size of pansy was influenced only by the temperature after VB. However, at least some of their data did show that flowers grown at constant $10{ }^{\circ} \mathrm{C}$ were $\approx 13 \%$ larger than those of plants grown initially at $25^{\circ} \mathrm{C}$ and then transferred to $10^{\circ} \mathrm{C}$ at VB. Conversely, when plants were grown at $10^{\circ} \mathrm{C}$ until VB and then transferred to $25^{\circ} \mathrm{C}$ until flower, flowers were $25 \%$ larger than those of plants grown at constant 25 ${ }^{\circ} \mathrm{C}$. In year 1, 'Blue Clips' and 'Birch Hybrid' plants that were exposed to high temperature before VB tended to have smaller flowers. The time from flower bud initiation to VB was 9.5, 6.5 , and $7.5 \mathrm{~d}$ at 14,20 , and $26^{\circ} \mathrm{C}$, respectively, for 'Deep Blue Clips' (Table 2). Cool temperatures from both flower bud initiation to VB and VB to flower may be critical for maximizing flower size. Time from flower bud initiation to VB may be $\approx 7 \mathrm{~d}$ for 'Blue Clips' and 'Birch Hybrid' at $20^{\circ} \mathrm{C}$, since time to flower for these species was similar to that for 'Deep Blue Clips' (Frane, 1999; Whitman et al., 1997). Thus, in order to maximize flower size, plants should not be exposed to high temperatures during the week before VB.

Increasing DLI before VB did not increase flower size or number of flower buds, although the low DLI level tested was above 5 $\mathrm{mol} \cdot \mathrm{m}^{-2} \cdot \mathrm{d}^{-1}$. Therefore, supplementary lighting to increase the DLI above $5 \mathrm{~mol} \cdot \mathrm{m}^{-2} \cdot \mathrm{d}^{-1}$ before VB is unnecessary for 'Deep Blue Clips'. However, supplementary lighting after VB partially compensated for the negative effect of high temperatures. For example, the number of flower buds was $\approx 40 \%$ higher under the high DLI ( 17 $\left.\mathrm{mol} \cdot \mathrm{m}^{-2} \cdot \mathrm{d}^{-1}\right)$ after $\mathrm{VB}$ at 22 to $24{ }^{\circ} \mathrm{C}$ than under the low DLI $\left(5.7 \mathrm{~mol} \cdot \mathrm{m}^{-2} \cdot \mathrm{d}^{-1}\right)$ at 14 to $16{ }^{\circ} \mathrm{C}$ (Fig. 3E), although flowers were larger at cooler temperatures.

Quantification of lateral branching is difficult in $C$. carpatica. Instead, the number of flower buds can be recorded to reflect branching status when the first flower is fully open, a high number of buds indicating more branching. Plants developed more lateral branches from their existing shoots as they elongated under high DLI after VB.

Since high DLI was obtained by supplementing natural light with HPS lamps, both light quantity and quality may have contributed to the increased number of flower buds. The ratio of red (R) to far red (FR) was 5.9 for HPS lamps (Whitman et al., 1998), but only 1.15 for sunlight (Smith, 1994). Thus, the actual R/FR ratio was higher in the high than in the low DLI treatments. High R/FR conditions enhance branching and suppress stem elongation (Smith,

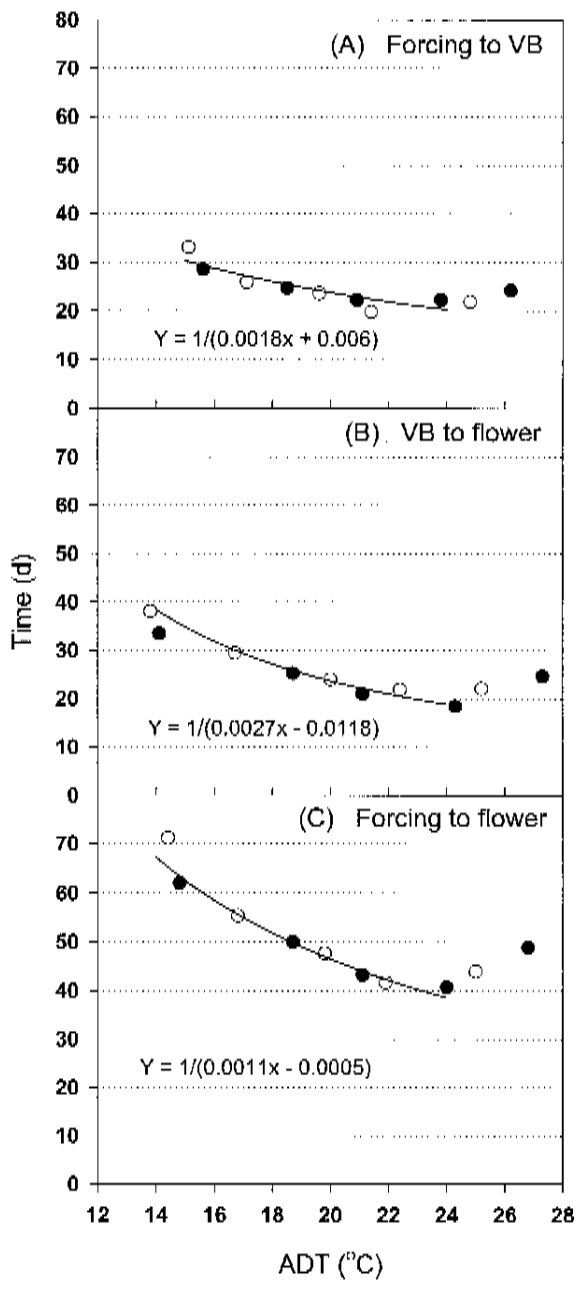

Fig. 4. Relationship between average daily temperature (ADT) and (A) time to visible bud (VB), (B) from VB to flower, or (C) from forcing to flower of Campanula carpatica 'Deep Blue Clips'. Symbols and $\bigcirc$ indicate high and low DLIs, respectively. The solid line represents the reciprocal of the developmental rate pooled from the two DLIs. Regression coefficients $\left(r^{2}\right)$ for developmental rate vs. ADT in the range of 14 to $24^{\circ} \mathrm{C}$ were 0.81 (forcing to VB), 0.98 (VB to flower), and 0.96 (forcing to flower), respectively.

1994). Plants were more compact under high than under low DLI.

Pearson et al. (1995) suggested that production of small pansy flowers at high temperature might be attributable to a reduced duration of flower development, which would limit the time for cell division or for cellular expansion. For the three species tested in our study, flower size increased linearly as the time from VB to flower increased (data not shown), indicating that the flowers were larger when the duration for flower development was longer. Since we did not measure cell number or size in flowers, we do not know which was affected.

In summary, flower size in 'Deep Blue Clips' decreased as the temperature before or after VB increased. The number of flower buds was not influenced by the temperature before $\mathrm{VB}$, while it was negatively correlated with the temperature after VB. Increasing DLI after VB increased flower size and number, but a DLI of 5.7 to $17 \mathrm{~mol} \cdot \mathrm{m}^{-2} \cdot \mathrm{d}^{-1}$ before VB did not affect flower size and number of flower buds in 


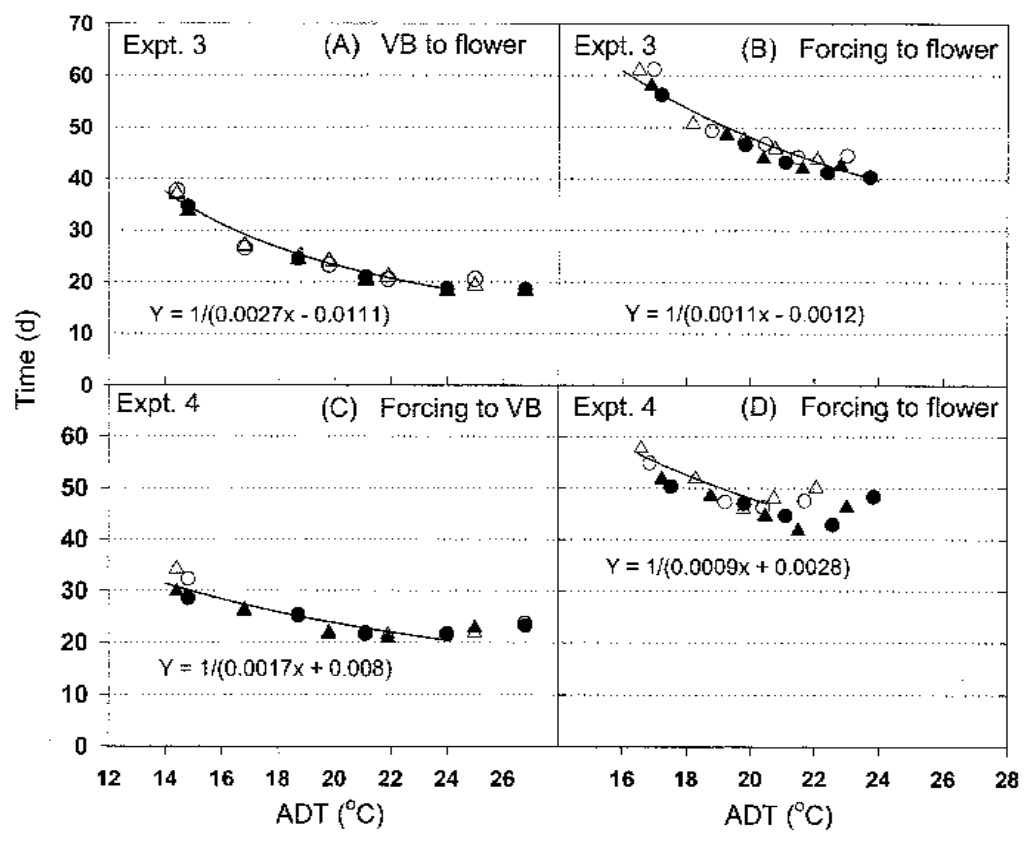

Fig. 5. Relationship between average daily temperature (ADT) and time (A) from visible bud (VB) to flower or (B) from forcing to flower of Campanula carpatica 'Deep Blue Clips' (Expt. 3); relationship between ADT and time to (C) VB or (D) flower (Expt. 4). Symbols indicate the DLI level before/after VB: High/High $(\bullet), \operatorname{High} / \operatorname{Low}(\bigcirc)$, Low/High $(\boldsymbol{\Delta})$, and Low/Low $(\triangle)$. The solid line represents the reciprocal of developmental rate pooled from all the combinations of DLIs before and after VB. Regression coefficients $\left(r^{2}\right)$ for developmental rate vs. ADT in the range of 14 to $24^{\circ} \mathrm{C}$ were 0.92 (Fig. 5A, VB to flower), 0.86 (B, forcing to flower), and 0.85 (C, forcing to $\mathrm{VB}$ ), respectively. That for developmental rate vs. ADT in the range of 16 to $20^{\circ} \mathrm{C}$ was 0.76 (D, forcing to flower).

Table 2. Time (days) to flower bud initiation and visible bud (VB) in Campanula carpatica 'Deep Blue Clips'.

\begin{tabular}{lrrr}
\hline \hline & \multicolumn{3}{c}{ Temp $\left({ }^{\circ} \mathrm{C}\right)$} \\
\cline { 2 - 4 } & 14.0 & 20.0 & 26.0 \\
\hline To flower bud initiation & 29.0 & 12.0 & 17.0 \\
To VB & 38.5 & 18.5 & 24.5 \\
From flower bud initiation to VB & 9.5 & 6.5 & 7.5 \\
\hline
\end{tabular}

'Deep Blue Clips'. For all species, flower size and number decreased as temperature after VB increased.

\section{Literature Cited}

Finical, L., A. Frane, A. Cameron, R.D. Heins, and W. Carlson. 1998. Forcing perennials crop by crop: Campanula 'Birch Hybrid'. Greenhouse Grower 16:121-124.

Frane, A.J. 1999. Temperature effect on timing and bud development of Coreopsis verticillata 'Moonbeam' and flower induction of long-day perennials under different night temperatures. MS Thesis, Dept. of Hort., Michigan State Univ., E. Lansing.

Niu, G., R.D. Heins, A.C.Cameron, and W.H.Carlson. 2001. Day and night temperatures, daily light integral, and $\mathrm{CO}_{2}$ enrichment affect growth and flower development of Campanula carpatica 'Blue Clips'. Scientia Hort. 87:93-105.

Pearson, S., A. Parker, S.R. Adams, P. Hadley, and D.R. May. 1995. The effects of temperature on the flower size of pansy (Viola $\times$ wittrockiana Gams.). J. Hort. Sci. 70:183-190.

Roberts, E.H. and R.J. Summerfield. 1987. Measurement and prediction of flowering in annual crops, p. 17-50. In: J.G. Atherton (ed.). Manipulation of flowering. Butterworths, London.

Serek, M. 1991.Effects of pre-harvest supplementary irradiance on decorative value and ethylene evolution of Campanula carpatica 'Karl Foerster' flowers. Scientia Hort. 48:341-347.

Smith, H. 1994. Sensing the light environment: The functions of the phytochrome family, p. 377-416 In: Kendrick and Kronenberg (eds.). Photomorphogenesis in plants. Kluwer Academic Publishers, Dordrecht, The Netherlands.

Whitman, C., R.D. Heins, A.C. Cameron, and W.H. Carlson. 1997. Cold treatment and forcing temperatures influence flowering of Campanula carpatica 'Blue Clips'. HortScience 32:861-865.

Whitman, C., R.D. Heins, A.C. Cameron, and W.H Carlson. 1998. Lamp type and irradiance level for daylength extensions influence flowering of $\mathrm{Cam}$ panula carpatica 'Blue Clips', Coreopsis grandiflora 'Early Sunrise', and Coreopsis verticillata 'Moonbeam'. J. Amer. Soc. Hort. Sci. 123:802807. 